\title{
UNIVERSITYOF
}

FORWARD

THINKING

WESTMINSTER用

WestminsterResearch

http://www.westminster.ac.uk/westminsterresearch

Making a Difference: Toward a Feminist Democratic Theory in the Digital Age

Asenbaum, $\mathrm{H}$.

This journal article has been accepted for publication and will appear in a revised form, subsequent to peer review and/or editorial input by Cambridge University Press in the Politics \& Gender. This version is free to view and download for private research and study only. Not for re-distribution, re-sale or use in derivative works.

(C) Cambridge University Press, 2019

The final definitive version in the online edition of the journal article at Cambridge Journals Online is available at:

https://dx.doi.org/10.1017/S1743923X18001010

The WestminsterResearch online digital archive at the University of Westminster aims to make the research output of the University available to a wider audience. Copyright and Moral Rights remain with the authors and/or copyright owners.

Whilst further distribution of specific materials from within this archive is forbidden, you may freely distribute the URL of WestminsterResearch: ((http://westminsterresearch.wmin.ac.uk/)).

In case of abuse or copyright appearing without permission e-mail repository@westminster.ac.uk 


\title{
Making a Difference
}

\section{Toward a Feminist Democratic Theory in the Digital Age}

\section{Hans Asenbaum, University of Westminster}

\section{Pre-edited version accepted for publication in Politics \& Gender on $18^{\text {th }}$ November 2018}

\begin{abstract}
This essay asks how the democratic ideal of inclusion can be achieved in societies marked by power asymmetries along the lines of identity categories such as gender and race. It revisits debates of difference democracy of the 1990's, which promoted inclusion through a politics of presence of marginalized social groups. This strategy inevitably entails essentializing tendencies, confining the democratic subject within its physically embodied identity. Difference democrats did not take notice of the parallel emerging discourse on cyberfeminism exploring novel identity configurations on the internet. This essay augments the politics of presence with digital identity reconfigurations. Neither difference democrats nor cyberfeminists distinguished between various participatory sites. Drawing on conceptions of participatory spaces from development studies and deliberative democracy, this essay generates a typology differentiating between empowered spaces such as parliaments, invited spaces such as citizens' assemblies, and claimed spaces of social movements. The democratic functions these spaces fulfil are best facilitated by three different modes of identity performance: identity continuation, identity negation, and identity exploration. A pluralization of participatory sites and modes of identity performance facilitates inclusion while tackling the essentializing tendencies in difference democracy.
\end{abstract}

\section{Introduction}

The profound changes in current societies are, among others, marked by two intertwined trends, the intensification of citizens' participation in politics and the increasing digitization of everyday life. Political apathy today is counteracted by intensified political participation in social movements, citizens initiatives and unconventional forms of engagement such as flash mobs and occupations (della Porta and Rucht 2013). Simultaneously, governments are developing new participatory formats such as citizens' assemblies, referendums, and participatory budgets (Smith 2009). The digitization of everyday life affecting the dynamics of work, love, family, and politics amplifies this trend. Social media that accompany our every step through the smart devices in our pockets increase participatory possibilities and extend communicative networks (Castells 2012). The \#MeToo debate, in which a social media hashtag connected a global bottom up campaign challenging patriarchal structures, provides a recent example.

Both these trends of increased participation and digitization are situated in a context of power asymmetries along social identity markers of gender, class, race, sexuality, able-bodiedness, etc. 
Such inequalities, perceptible by hard indicators such as income and soft indicators such as respect, result in the exclusion of marginalized groups from and within democratic participation. Thus, democratic theory with its ideal of equality faces the challenge of conceptualizing inclusion in digitized participatory societies marked by structural power asymmetries.

Contemporary feminist theory has extensive expertise regarding the exclusion of marginalized groups. However, feminism and democracy are two concepts mostly discussed in isolation from each other. While the core ideas of equal rights and social status of the sexes and equal rights and influence of all citizens in political decision-making share a lot of common ground, democratic theory has been reluctant to acknowledge feminist thought. This neglect is regrettable as feminist debates offer crucial insights, particularly when taking the emancipation of the sexes as a starting point and conceptualizing feminism as a broad movement against identity-based discrimination. In the groundbreaking essay "Feminism and Democracy" the leading democratic theorist Carole Pateman (1989) was the first to articulates a vision of democracy that "extends beyond the state to the organization of society... Democratic ideals and politics have to be put into practice in the kitchen, the nursery, and the bedroom" $(220,222)$.

The great potential of combining feminist and democratic theory was explored for a short period of time in the 1990s by so called "difference democrats" (e.g. Mansbridge 1993; Phillips 1993; Young 1997). Their rich discussions promoted inclusion in democracy through a performative politics of presence. Mirror or special representation through quotas were advanced to include marginalized groups into the public sphere. Difference democrats themselves, however, extensively discussed a dilemma inevitably accompanying this strategy. The organic body of the individual democratic subject became not only the intended site of resistance to domination but also a site of confinement. Claiming identity through physical presence entails essentialist tendencies, reinforces stereotypical thinking, and traps the individual in its body, impeding the possibility of identity change.

Difference democrats' discussions in the 1990s did not take notice of the parallel emerging discourse about novel identity configurations on the internet. Cyberfeminist thought in media, communication, and Science and Technology Studies (STS) developed a different understanding of democratic subjectivity (e.g. Haraway [1985] 1991; Turkle 1984). In contrast with the physically embodied subject with its stable identity markers, the reconfigurations of the organic body through technology allowed for novel cyborgian corporealities. While sharing the idea of inclusion through embodied presence with difference democrats, cyberfeminists redefine presence through new modes of digital embodiment, anonymity, and identity play. 
This essay deepens difference democratic thought by incorporating cyberfeminist insight. It augments the politics of presence with a notion of digital presence to answer the question: How can inclusion be advanced in societies marked by identity-based power asymmetries? Both difference democratic and cyberfeminist thought contributes to inclusion in democracy, but their focus on one type of identity performance only limits their scope. Moreover, they both neglect to differentiate between participatory sites and their respective functions in democracy. In contrast, I propose that the essentializing tendencies in difference democracy can be tackled by expanding the array of identity performances. This can be achieved through a pluralization of participatory sites and their respective democratic functions. Social movement activists, for example, fulfil different democratic functions than parliamentary legislators and thus best contribute to inclusion through different identity performances. The solution to the difference democrats' essentializing dilemma can be found in difference democracy itself. It is its core value of pluralism that leads the way out.

To achieve this differentiation, I further develop the debates on difference democracy and cyberfeminism with the concept of participatory spaces generated in feminist development studies (Brock, Cornwall, and Gaventa 2001) and deliberative democratic theory (Dryzek 2009), distinguishing empowered spaces such as parliaments, invited spaces such as citizens' assemblies, and claimed spaces such as social movement organizations. I propose a typology, which outlines which digital identity performance (identity continuation, identity negation, identity exploration) in which participatory space (empowered, invited, claimed) best contributes to which democratic function (accountability, equality, freedom). This typology might be of use to democracy scholars, activists, and state agents to think more adequately about the variability of identity performances and democratic functions of different participatory spaces.

The main purpose of this article is thus to investigate the positive contributions new means of performing identity through online media can make to participatory democracy. When raising this question, the negative effects of digital communication must not be overlooked, however. Extensive empirical literature illustrates how online communication is frequently marked by group polarization, fraud, cyberbullying, and hate speech (e.g. Sunstein 2017). The digital divide and digital inequalities, moreover, exclude large numbers of citizens from participation altogether (CamposCastillo 2015). For a critical feminist inquiry, it is imperative to ask, how these challenges interact with new participatory spaces on the internet. Do digital participatory spaces exacerbate or mitigate discrimination, exclusion and deception as widely observed in everyday online communication?

To move toward a new feminist democratic theory in the digital age, this essay first revisits difference democracy and the notion of inclusion through physically embodied presence. It then moves on to cyberfeminist thought on digital reconfigurations of democratic subjectivity. Drawing on the concept of participatory spaces, the third section develops a typology showing how different 
modes of identity performance in different participatory spaces fulfil different democratic functions. This typology is illustrated by a review of empirical studies on online participation.

\section{Difference democracy: A feminist challenge to democratic theory}

Rather than a coherent model of democracy, what came to be termed "difference democracy" (Dryzek 2000, 57) is a diverse feminist discourse in democratic theory promoting inclusion in participatory processes in the context of structural inequalities. Jane Mansbridge's Beyond Adversary Democracy (1983) played a crucial role in setting the agenda. Her empirical investigation evidenced participatory inequalities along the lines of gender, race, and class in a New England Town Hall meeting and in a case of workplace democracy, illustrating how members of marginalized groups spoke less and felt less influential.

The agenda set forth by Mansbridge critically resonated with conceptions of deliberative democracy emerging at this time. While sharing the goal of inclusion with deliberative democrats, difference democrats charged the original conceptions of deliberation with androcentrism and Eurocentrism. Generated by white, male academics, the universalizing conception of rational knowledge is deeply rooted in Western Enlightenment thinking. The focus on dispassionate, factoriented discussion with the force of the better argument contributing to consensus-finding tends to silence marginalized social groups. This results in internal exclusion - the devaluation of content uttered by those with low identity-related social status (Young 2000). In her seminal essay “Against Deliberation” Lynn Sanders argues: "[T] aking deliberation as a signal of democratic practice paradoxically works undemocratically, discrediting on seemingly democratic grounds the views of those who are less likely to present their arguments in ways that we recognize as characteristically deliberative. In our political culture, these citizens are likely to be those who are already underrepresented in formal political institutions and who are systematically materially disadvantaged, namely women; racial minorities, especially Blacks; and poorer people” (Sanders 1997, 384). ${ }^{1}$

The problem of internal exclusion has been evidenced in a wide array of empirical work since Mansbridge's (1983) study. The extensive experimental work of Christopher Karpowitz and Tali Mendelberg (2014) documented in The Silent Sex finds that overall women speak less in deliberative settings. Edana Beauvais (2017) finds not only that women and ethnic minorities speak less, but also are audience members more easily swayed by comments made by men. The gender gap in classical forms of political participation such as voting has closed recently in Western societies (Nancy Burns et al. 2018). Upon closer examination, however, inequality persists. A recent study of 18 Western countries finds that while women vote and petition at higher rates than men, they are less likely to participate in civil society initiatives and collective action. These patterns point to internal exclusion: women participate less in face-to-face deliberative settings because they feel 
unwanted or intimidated (Coffé and Bolzendahl 2010). This is also mirrored in a dramatic gender gap in political ambition to engage in politics among youth (Fox and Lawless 2014).

To tackle the problem of internal exclusion, difference democrats promote diversity as a resource for deliberation. Iris Marion Young, for example, observes the emergence of a heterogeneous public in contrast to Habermas' universal public sphere. Here Red and Black Power, LGBTIQ, and women's movements articulate diversity. "In this vision the good society does not eliminate or transcend group difference. Rather, there is equality among socially and culturally differentiated groups, who mutually respect one another and affirm one another in their differences" (Young 1990, 163). Difference is not perceived as obstacle, but as resource for deliberation enabling mutual growth (Young 1997b). In the same vein, Nancy Fraser (1990) observes the formation of subaltern counterpublics by marginalized social groups as safe spaces to develop counter discourses that challenge hegemonic narratives.

Beyond diversifying politics through social movements, many difference democrats call for extending the scope of participatory democracy. According to Carole Gould (1996), the best way of facilitating presence for marginalized groups is by creating self-managed participatory assemblies in the workplace and education. Others focus on inclusion in parliamentary institutions. Anne Phillips (1995) argues that the notion of diversity has always been a core concept in the liberal, pluralist tradition. However, pluralism was only applied to ideas and not to identities. While liberalism declares individuals equal in value and rights, it overlooks structural inequalities along identity cleavages. According to Phillips, the composition of parliamentary bodies does not only need to reflect a pluralism of ideas but also a pluralism of identities.

\section{Physically embodied presence as political claim}

In difference democratic debates, the corporeal identity of marginalized subjects functions as visible claim for inclusion. Phillips (1995) argues that the liberal politics of ideas, which only pays attention to content and neglects identities, is now challenged by a politics of presence. Giving preference to Hanna Pitkin's concept of "standing for" rather than "acting for," Phillips contends that only by claiming presence in public assemblies such as parliaments and activist meetings can marginalized groups draw attention to their particular experiences. Similarly, Mansbridge argues: "Even when the descriptive legislator is silent, his or her mere physical presence reminds the other legislators of the perspectives and interests of the group of which he or she is a descriptive member" $(2005,626)$. It is thus the visibility of the physical body that articulates a political claim.

According to many difference democrats, political claim-making through embodied presence is valid because different bodies represent different social positionalities. Since men and women, heterosexual and LGBTIQ, black and white people are forced into different social positions, they 
also bring different qualities to the public. The presence of women in political decision-making processes is often advocated by pointing to specific womanly qualities stemming from particular socialization. According to this argument, women's experience of mothering contributes to a caring and nurturing orientation. Mansbridge $(1993,345)$ argues that empathy, sensitivity, and intuition as female characteristics are constitutive for democratically organized communities, which rely on social connections of trust, love and duty. Some difference feminists interpret this as a superior culture of women who excel at persuading, listening, asking questions, moderating, and integrating (Mansbridge 1991, 126-128). And Gould draws parallels between female nurturing and the redistributive functions of the state: "I also believe that the typical concern for providing for the specific needs of others associated with mothering or parenting... can usefully be imported into the larger democratic community" (1993, 405).

To facilitate access of marginalized groups to political institutions, many difference democrats advocate quotas. While Mansbridge $(1999 ; 2005)$ and Phillips $(1991 ; 1995)$ favor descriptive or mirror representation, Young $(1990 ; 1997 \mathrm{a} ; 2000)$ calls for special representation of groups who suffer from the long-term effects of historic oppression. According to Young, the current system of party representation needs to be supplemented by a structure of self-organized associations of marginalized groups wielding veto power in decisions of their direct concern. These measures need to be accompanied by affirmative action in education and employment.

\section{The dilemma of difference}

While difference democrats' discussions about identity, inequality, and inclusion provide an invaluable contribution to democratic theory, their argument is also haunted by an inherent conundrum. Difference democrats themselves have repeatedly pointed out a paradox: The politics of presence furthers inclusion through visibility of marginalized groups, however, it simultaneously reinforces dominant modes of identity construction (Mansbridge 1993, 371; 1999, 637; 2005; Phillips 1991, 72; Young 1990, 172; 1994; 1997a, 350; 1997b, 386). Young calls this the dilemma of difference. If black people are supposed to speak for black people by virtue of their corporeal attributes, the identity of the individual is fixed in accordance with the associated group identity, personal preferences are undermined, and stereotypes are activated. According to Young: "The unifying process required by group representation inappropriately freezes fluid relational identities into a unity, and can recreate oppressive segregation" (Young 1997a, 350). Similarly, Mansbridge elaborates: "Essentialist beliefs reinforce stereotypes, trap the individuals in the group in the images traditionally held of the group, make it hard for those individuals to treat their identities flexibly and performatively, de-emphasize lines of division within groups to the advantage of dominant groups within the group, and harden lines of division between groups" (Mansbridge 2005, 623). 
Social movements promoting the affirmation of group difference might be successful in reinterpreting their identities in positive terms, but in doing so they also affirm identity confinements. Labels such as "woman," "gay," "lesbian," "black," “Asian," "Jew” always demarcate definitions, which limit individual self-expression and identity exploration. These confinements become even more problematic considering intersectionality and uneven power relations in the process of identity construction. The notion "woman," for example, is mostly created by white, heterosexual, ablebodied women with higher incomes and thus rarely reflect the experience of LBTIQ, black, disabled, and poor women (Fraser 1996, 200). Young's criticism of "cultural imperialism" imprisoning members of marginalized groups in their bodies marked as deviant Other (Young 1990, 123) thus partly also applies for positive reinterpretations of these identities. The new prison might benefit from an improved image, but it is a prison nevertheless.

\section{Cyberfeminism: Materializing difference through the digital}

Difference democrats' discussions in the 1990's did not take notice of the parallel emerging discourse about novel identity configurations on the internet, which promises to shed new light on the dilemma of difference. In the 1980's, feminist scholars started exploring new modes of digital communication (e.g. Haraway [1985] 1991; Turkle 1984). These discussions came to be identified with the term "cyberfeminism." Cyberfeminist discourses, on the one hand, promoted diversity through the digital performance of marginalized identities in digital counterpublics - very much in line with the ideals of difference democracy. On the other, they explored the liberating effects of anonymity (Author 2108). What emerges in cyberfeminist thought are conceptions of digital presence, which allow for a re-reading of difference democracy.

Cyberfeminism as movement extends beyond academia and fuses discussions from three sources: feminist scholarship, digital art projects such as the Old Boys Network (www.obn.org) and SubRosa (cyberfeminism.net), and online women's empowerment projects including peer-support groups (Fernandez and Wilding 2002). The equal importance of feminist scholarship and empowered practice for cyberfeminism as a movement, is also exhibited in the fact that the term "cyberfeminism" was simultaneously coined in 1991 by the British cultural theorist Sadie Plant and the Australian art collective VNS Matrix (Volkart 2004, 97). The roots of cyberfeminist discourse go further back than the emergence of the term, however.

\section{Rise of the cyborg}

Before the term cyberfeminism was coined, scholars such as Donna Haraway and Sherry Turkle laid the ground for later work on digital presence. In “A Cyborg Manifesto," Haraway ([1985] 1991) starts from the same point of critique as Young (1990) and other difference democrats: “Gender, race, or class consciousness is an achievement forced on us by the terrible historical experience 
of the contradictory social realities of patriarchy, colonialism, and capitalism" (155). Like Young (1990), Haraway points to the construction of binary categories such as male/female, civilized/primitive, and mind/body defining one element as inferior to the other. However, unlike Young's difference as resource for deliberation aiming at equalizing the value of both elements, Haraway proposes the metaphor of the cyborg as monstrous hybrid breaking out of this dichotomous thinking altogether. By reconfiguring human/machine, animal/human, and physical/nonphysical, the cyborg does not, however, merge these binaries into a new unity, a dialectical synthesis, but rather leaves the riddle unsolved. The irony of the cyborg is constituted by its plurality dissolving unity into contradiction. Haraway encourages giving up the struggle for clearly demarcated identities and indulging in the pleasures of the cyborg - the pleasures of disorientation. Binary gender codes are reconfigured into "partial, contradictory, permanently unclosed constructions of personal and collective selves" (Haraway [1985] 1991, 157).

Haraway's cyborg dream leaves the figure of the cyborg itself mainly obscure. What cyborgs could be in current societies is made comprehensible in Sherry Turkle's Second Self (1984) - albeit without using the term "cyborg." In her psychological ethnography of user interaction with computers, Turkle explores human/machine hybridity: "We search for a link between who we are and what we have made, between who we are and what we might create, between who we are and what, through our intimacy with our own creations, we might become" (2). Computers simultaneously appear as objects - as tools used by human subjects - and as thinking subjects, which call upon their users. Humans can employ computers as tools to create their own individual worlds. As soon as humans enter these worlds, however, they are affected by them. Humans are subjected as "computers enter into the development of personality, of identity, and even of sexuality" (ibid., 6). The hybridization of human/machine emerges in a move of reciprocal affectivity. On the one hand, users humanize computers as "friends" that "are stupid" at times or need to "rest for a while." On the other, users reimagine themselves in technological terms as they might not "function well" or conceptualize their forgetfulness as information being "erased from the hard drive" (ibid., 7).

According to Turkle, computers function as mirrors for the individual self. The metaphor of Narcissus, which has been misinterpreted in the past, helps to understand this mirror function. Narcissus did not fall in love with himself out of vanity, but seeing his reflection in the water he perceived himself as someone else, thus falling in love with the self as other. Computers provide mirrors to see the self as reconfigured other. It objectifies the self, resulting in a representational object vis-à-vis the self. This objectified other/self does not serve vain self-love, but the anxious search for the self, as reassurance of our own existence, stability, and unity. Turkle aptly captures Haraway's complex notion of the disorientation of the cyborg: "Where we once were rational animals, now we are feeling computers, emotional machines. But we have no way to really put these terms 
together. The hard-to-live-with, self-contradictory notion of the emotional machine captures the fact that what we live now is a new and deeply felt tension" (ibid., 326).

\section{Identity play in a world beyond zeros and ones}

These theories of the cyborg as a subject formation that disrupts modern identity categories is put into relation with online communication in Sadie Plant's book Zeros + Ones (1997). Plant attests the disorder of binary identity codes rooted in Western thinking that was also criticized by Haraway and Young. This identity disruption is amplified by new possibilities of anonymous communication and identity play online. Plant illustrates this reconfiguration of gender identities along the computational logic of zeros and ones. While in traditional Western thought, the phallic 1 is associated with presence, power, and masculinity, women are associated with the 0 as absence, passivity, powerlessness, a nothing, a gap, a hole. In this metaphor, men are everything and women nothing, an image corroborated by the division of global wealth and political power. The computer disrupts this binary logic, however, and turns the established binary upside down. In original computer punch cards the 0 constitutes the something and the 1 the nothing: "No longer a world of ones and not-ones, or something and nothing, thing and gap, but rather not-holes and holes, not-nothing and nothing, gap and not-gap" (ibid., 57).

Plant's narrative of the history of computing relocates the focus to the forgotten contributions of women, such as Ada Lovelace whose work in the 1840s foresaw the potentials of computing beyond mere calculation (also cf. Evans 2018). Women mostly, however, executed repetitive work to fulfil plans developed by men. When weaving was automated through punch cards as an early form of computational automation, women moved to the industrial assembly lines and functioned as gearwheels along with industrial machines. Today it is women in the Global South, mainly in Asia, who assemble computers for use in the West. Plant describes an intimate relationship between women and machines both abused as tools of men. She invokes the many popular fictional narratives of robots, often designed as women and thus connoted with the idea of sexual objectification, who rebel against their human, male creators.

Plant's Zeros + Ones has been highly influential in early cyberfeminist writing. Both Danet (1998) and Sick (2004), for example, explain online avatars as masquerade disrupting traditional gender identities and Volkart (2004) describes the cyberfeminist subject as unruly cyborg, revolting against male domination. Plant's book has, however, rightfully been criticized for its techno-determinism and its essentialist reproduction of stereotypical gender roles, although reinterpreting them in positive terms (Wajcman 2004, 73) much like some difference democrats.

Recent cyberfeminist work turns to the corporeal configurations of the cyborg and investigates digital presence. The collected volume Cyberfeminism 2.0 (Gajjala and Oh 2012), for examples, 
examines digital space as marked by patriarchal and capitalist inequalities that are contested by feminist presence. In "Developing a Corporeal Cyberfeminism" Brophy (2010) attempts to "rehabilitate" cyberfeminism through the concept of liminality. Drawing on Elizabeth Grosz's (2001) "in-betweenness" she explains new subject constitutions through the digital as a change in the perception of reality both online and offline. In a similar vein, Jessie Daniels" "Rethinking Cyberfeminism(s)" (2009) draws attention to re-embodiment on the internet. Through examples such as websites that facilitate peer advise on transsexual body transformation she illustrates how the participatory possibilities of online engagement are used in subaltern counterpublics to construct alternative body images. This can be read as an emancipatory move of marginalized groups to take control of the construction of their own body and challenge hegemonic body images. In a circular process, images of the physical body are replicated online and then in turn affect the perception of the body offline and can even entail physical body transformation.

Thus, while early cyberfeminist writing of Haraway, Turkle, and Plant focuses on ephemerality and identity play, current cyberfeminists situate themselves much closer to difference democrats' politics of presence by focusing on analog/digital identity continuities, thus paying closer attention to the limits of identity play and its stereotyping effects (Nakamura 2002), while still attesting possibilities for transformation. They, moreover, take the notion of the cyborg further by applying it not only to online identities like Plant but by grasping the offline reconfigurations of embodiment through a digitally altered perspective on the self.

\section{Toward a feminist democratic theory in the digital age}

While there is some agreement about the importance of identity and the inclusion of marginalized groups between difference democrats and cyberfeminists, their conceptions of identity differ quite significantly. Table 1 summarizes similarities and differences.

Table 1: Comparison between Difference Democracy and Cyberfeminism

\begin{tabular}{|l|l|l|}
\hline & Difference Democracy & Cyberfeminism \\
\hline Political goal & Inclusion & Inclusion \\
\hline Space of political interaction & Analog face-to-face & Cyberspace, liminal space \\
\hline Mode of presence & Physical presence & Digital presence \\
\hline Identity performance & Stable & Mutable \\
\hline
\end{tabular}

Both difference democrats and cyberfeminists contest gendered power asymmetries by focusing on particular modes of identity performances. Cyberfeminist perspectives allow for the 
conceptualization of a politics of presence online. The difference democratic notion of physical presence can thus be supplemented with a cyberfeminist notion of digital presence. This sheds new light on the dilemma of difference. The essentializing tendencies in difference democratic thought can be countered by opening up possibilities of exploring multiple identity configurations in the liminal spaces between and beyond online and offline. Cyberfeminists draw attention to the value of anonymity. This does not merely entail hiding identity, which has rightfully been criticized as contributing to the invisibility and further marginalization of disadvantaged groups (Kolko 2000). Rather, anonymity consists as much of identity creation as of identity negation and thus constitutes a specific type of identity performance (Author 2018). As the rest of the paper will demonstrate, promoting diversity is possible through digital corporealities that continue as well as discontinue physically embodied identities. Thus, a cyberfeminist notion of digital presence can supplement difference democrats' politics of presence and contribute to the overarching goal of inclusion.

Difference democrats developed their accounts of inclusion in relation to three types of political institutions in society: representative state institutions, citizens' participatory institutions, and social movements' organizations. They, however, did not differentiate the mode of identity performance for these three types, proposing continuous identity performances for all of them instead. In contrast, I argue that different institutions fulfil different democratic functions which are best facilitated by different modes of identity performance. To generate this differentiation, I draw on the concept of participatory spaces emerging in feminist development studies (Brock, Cornwall, and Gaventa 2001; Cornwall 2002; 2004; Gaventa 2006; Cornwall and Coelho 2007) and deliberative democratic theory (Dryzek 2009). ${ }^{2}$

Discussions about participatory spaces distinguish empowered spaces such as parliaments, invited spaces such as citizens' assemblies, and claimed spaces such as social movement organizations. This differentiation enables us to grasp political participation in three different academic fields: First, the study of parliamentary deliberation gives insight into legislative decision-making processes (Bächtiger et al. 2005). Second, the study of democratic innovations is rich in empirical findings on participatory designs such as mini-publics, town meetings, participatory budgets, petitions, referendums, and consultations (Smith 2009). Third, the study of social movements and collective action has recently employed democratic theory to understand internal decision making where "forms of power intervene in the communicative arenas that social movements build and inhabit" (della Porta and Rucht 2013, 4; also cf. Polletta 2002). The concept of empowered, invited, and claimed spaces allows for thinking these three types of participatory arrangements together. The crucial differentiation between these spaces is informed by the social positionality of the creators of the respective space and the actors within them. In short, it is determined by the question: Who created the space for whom? Empowered spaces are created by the state and facilitate the 
interaction of state actors; invited spaces are created by the state for citizens; and claimed spaces are created by citizens for their own interaction.

The metaphor of the space serves to translate the notion of physical relationality into social relationality: "Thinking about participation as a spatial practice highlights the relations of power and constructions of citizenship that permeate any site for public engagement" (Cornwall 2004, 1). Furthermore, space as a relational concept makes imagining a discursive power architecture possible. Participatory interfaces are to be carefully constructed to challenge asymmetrical power relations inscribed in societies. In line with difference democrats' pursuit of inclusion, Andrea Cornwall (2002) argues: "Some participatory approaches explicitly seek to disrupt the order of hierarchical institutions, creating new and different spaces in which different rules of the game offer otherwise silenced actors a chance to speak and be heard" (7). At the same time, however, participatory design can function as a tool of political elites to coopt participants (Font et al. 2017).

The differentiation between types of spaces contributes to finding new answers to the question of inclusion in unequal digitized societies. Looking at political engagement on the internet, each type of participatory space with its different actors contributes to a different democratic function through different modes of identity performance as illustrated in Table 2. All of these identity performances and their respective democratic functions serve the overarching goal of inclusion.

Table 2: Typology of identity performances in participatory spaces on the internet

\begin{tabular}{|l|l|l|l|}
\hline & Empowered spaces & Invited spaces & Claimed spaces \\
\hline Actors & State agents & State agents, citizens & Citizens \\
\hline Identity performance & Identity continuation & Identity negation & Identity exploration \\
\hline Democratic function & Accountability & Equality & Freedom \\
\hline
\end{tabular}

Empowered spaces such as parliaments need to fulfil the democratic function of accountability to create a strong link between citizens and their representatives (Dryzek 2009, 1386). The dialogical process of giving and holding to account includes various ideas of various constituencies into the democratic system. Accountability is facilitated by identity continuation - the performative enactment of physically embodied identity as advocated by difference democrats. As a communicator in empowered spaces, the democratic subject acts as a representative of the social group it is associated with by virtue of the identity markers inscribed in its body and performed through sociocultural codes of clothing, body language, etc. In regard to online communication, such continuous identity performances are possible through the digital replication of analog identity performances. 
Invited spaces are designed to facilitate inclusive dialogue and are oriented toward the ideal of freedom from domination (Smith 2009, 22). In contrast with both empowered and claimed space, invited spaces generate short-lived encounters between citizens and between citizens and state agents. They call for short term solutions to problems of internal exclusion (Young 2000). Digitally enabled identity negation corresponds to this logic. It reduces stable identity markers to a minimum such as individual pseudonyms, the collective moniker "anonymous" or no identifiers at all. This does not do away with identity, it rather facilitates identity expression. Diversity is claimed linguistically rather than visually. Identity boundaries are, however, destabilized (Author 2018).

Claimed spaces, finally, flourish on identity exploration to facilitate expressive freedom, as suggested by cyberfeminists. Claimed spaces on the internet allow for the visual enactment of identity through avatars, pictures, videos, emoticons and other digital reifications of corporeality. This identity exploration of the individual serves the freedom to rediscover and playfully express the multifaceted self. It thus contributes to inclusion of various aspects of identity into the democratic system. Identity exploration corresponds with social movements' need to communicate with the public. To be heard in a competitive media environment, they need to form colorful and innovative collective identities and engage in carnivalesque forms of protest.

The typology presented in Table 2 is not rigid. While the mode of identity performance and the respective function are indeed closely linked, the type of participatory space in which they might occur needs to be treated more flexibly. Accountability through identity continuation, for example, can be important in invited spaces as well just as identity negation and equality might be vital in claimed spaces. The following review of empirical work on the subject, however, will demonstrate that the respective identity performances and its functions mostly occur in the participatory spaces indicated in Table 2. It shows how these democratic functions come into play and what designers of participatory spaces need to take into account in order to best facilitate them.

\section{Empowered spaces on the internet: Accountability through identity continuation}

Empowered spaces as democratic forums legitimized by the citizenry to make political decisions on their behalf are increasing their online presence (Stanyer 2008). New digital modes of identity construction are used by governmental actors to fulfil their function as representatives of their respective constituencies. In practical terms, this means that representatives carefully select and curate images and text including biographies and information on current activities. These visual and textual self-portraits replicate representatives' analog identities. In a study on US Members of Congress, Gulati (2004) explains: "the images and symbols that members of Congress include on their Web sites are meant, at the very least, to be consistent with the impression of themselves that they are trying make with a constituent during a face-to-face meeting" (25). This is corroborated by 
Stanyer (2008) in a study on US and UK legislators, who “... will seek to project the same identity (they will not appear as someone else) and emphasize the same qualities" (419).

These continuous identity performances serve the democratic function of accountability connecting representatives to their constituencies. Only through identity continuation can representatives be held accountable. Thus, one of the prime goals of digital government policies is to increase transparency. Not only does this enhance public scrutiny of governmental activities, it also strengthens the bond of constituents with their representatives: "While transparency of parliamentary procedures including committee deliberations, parliamentary debates, MP [Member of Parliament] voting records and MP absenteeism is clearly important for public accountability, transparency of actual MP characteristics (that is, personal and contact information) can likewise enhance the quality of governance by increasing public awareness, legitimacy, and trust in both Parliament and individual MPs" (Joshi and Rosenfield 2013, 528).

Setälä and Grönlund (2006) go beyond the notion of transparency and claim that legislators' digitized identity performances facilitate publicity. Unlike transparency, which describes the mere possibility of public scrutiny, publicity facilitated by representatives' websites strengthens interactivity. The act of holding representatives accountable is a two-way conversation which also comprises civic feedback. This input function of accountability allows for the inclusion of public opinion in governmental decision-making. While the possibilities for public feedback to legislators' have been significantly increased through new media, several studies show that most of representatives' websites grossly neglect the opportunity for interactivity (e.g. Jackson and Lilleker 2009).

Representatives' websites are rather used for one-way communication and identity construction contributing to difference democrats' ideal of embodied diversity. A recent study finds that $61 \%$ of parliamentary websites worldwide display photos of legislators, $67 \%$ indicate their sex, and 44\% their age (Joshi and Rosenfield 2013). These numbers are higher in wealthier nations such as the US where $100 \%$ of the websites of Members of Congress contain information on education and experience, $78 \%$ on local roots, and $90 \%$ on family relations. Representatives" official governmental websites are complemented by their social media presence. The compilation of several identity performances on various web domains has been theorized as "networked self" in the work of feminist media scholars (Cohen 2012; Papacharissi 2011). Empirically, 21\% of legislators worldwide were found to use social media (Joshi and Rosenfield 2013). Legislators' social media presence also entail a gendered aspect. While only 19.4\% of UK MPs are women, 29.4\% of MPs actively engaging on Twitter are women (Jackson and Lilleker 2011) giving some credibility to the cyberfeminist thesis of women's empowerment through online engagement. 


\section{Invited spaces on the internet: Equality through identity negation}

Invited spaces such as citizens' assemblies and participatory budgets are increasingly replicated online or make use of hybrid online/offline engagement (Smith 2009, 142-160). Whereas in empowered spaces only state agents interact and the democratic function of accountability links them to the citizenry, invited spaces serve as an interface between citizens and state representatives, be this directly through the digital interaction of citizens with state agents or indirectly through governmental engagement with the discursive output of these spaces (Peixoto and Fox 2016).

Invited spaces online are carefully designed to afford inclusive processes of citizens' participation, with the literature focusing on design feature such as facilitation, co-temporality (a-/synchronicity), and identifiability (Davies and Chandler 2012). The latter feature proves especially significant. Unlike their analog counterparts, online spaces provide the opportunity for the temporal negation of physically embodied identity. This potentially counters prejudice and discrimination that are prevalent in face-to-face encounters. It levels the playing field and promotes meritocracy.

In 2000, for example, the UK parliament in cooperation with the Hansard Society organized an online consultation process entitled Womenspeak. The online forum invited both MPs and victims of domestic violence to discuss their personal experiences under self-selected pseudonyms. The crucial role of avoiding identification is pointed out by Margarete Morgan, an MP taking part in the process: "The anonymity offered by the technology enabled women to tell their stories, often for the first time, without fear of identification and to receive support and advice without fear of reprisal" (cited in Smith 2009, 154). Coleman (2004) finds that 85\% of participants in Womenspeak reported to perceive the online forum as a safe space: "Had the participants been invited to attend Parliament to tell their stories and express their views, few would have gone. Parliament is an intimidating place and most women would not want their names recorded as witnesses" (6). This case illustrates difference democrats' counterpublics as enclave deliberation of disadvantaged groups (Fraser 1990). At the same time, it exemplifies a cyberfeminist practice of peer support. At the end of the process, several participants posted enthusiastic comments such as: "It was brilliant; I felt really close to the participants during the consultation as if I were part of a giant support network" (cited in Coleman 2004, 8).

While this example aptly illustrates the inclusive function of identity negation in invited spaces online, it is possible that this is only due to the particularly vulnerable position of participants. Other examples, however, show that temporal identity negation can contribute to equality in other contexts as well. An experiment on a political discussion forum to debate the upcoming South Korean national election in 2004 found that participants who had to reveal their gender, age, and region engaged less frequently than those who stayed anonymous. The authors of the study explain: 
"Physical appearance or social status (perceived) in face-to-face interactions often function as 'gates' that control human interaction. Anonymity in computer-mediated communication frees interaction participants from potentially feeling socially inferior to their counterparts and, thus, facilitates expression for everyone" (Rhee and Kim 2009, 225).

This feeling of inferiority can further be explained by the "chilling effect." The feeling of being observed and judged by others leads to inhibition and stifles free expression. This chilling effect observed on social media where users self-censor due to government surveillance (Stoycheff 2016) also comes to bear in invited spaces on the internet, where participants potentially feel judged by their gender, race or other identity markers. Anonymity can thus work against the chilling effect and alleviate peer pressure and concerns about surveillance. A study comparing anonymous and identified online petitioning found that the willingness to sign petitions drops by $8.5 \%$ if identification is required (La Raja 2011). Other studies show that when given the choice, large shares of online petition signers opt for anonymity (Berg 2017; Schmidt and Johnsen 2014). Similarly, participation numbers dropped drastically in the online participatory budgeting process in the German city of Gütersloh when mandatory identification was introduced. While in 2011 with the option of anonymity $1.7 \%$ of population took part, this number decreased to $0.4 \%$ in the consecutive year where identification was required (Ruesch and Märker 2012).

The effect of diminished participation through enforced identification comes along with significant gender differences: The study on online petitions found that while men are hardly affected by required identification, engagement of female participants drops significantly. The author reasons that women are more heavily affected by peer pressure: "While women now vote at equal rates to men, their participation remains unequal with respect to... other forms of participation. Disclosure policies appear to depress this participation even more" (La Raja 2011, 21).

\section{Claimed spaces on the internet: Freedom through identity exploration}

Claimed spaces on the internet are either created as alternative media or occupy commercial space on corporate social media such as Facebook or Instagram. They make use of opportunities for digital identity change, which is not a serious endeavor but a playful undertaking. The carnivalesque act of masking constitutes a transformative practice of challenging the stability of identity (Bakhtin 1968). Today carnivalesque protest with its roots in European medieval Mardi Gras, which often entailed the mockery of ruling authorities and the playful inversion of social hierarchies, meet the possibilities of online identity play described by cyberfeminists.

Both cyberfeminist practice and carnivalesque protest are aptly illustrated by the New York art collective Guerilla Girls. Their public interventions in the disguise of gorillas dating back to 1985 have made use of digital media in recent years. Digital identity performances extend the 
analog possibilities of roleplay through digital images and videos of gorilla performances enacting aggressiveness and masculinity. Particularly, the breakaway-group Guerilla Girls Broadband have created a subversive online presence. On their website, users can join by virtually dressing up as gorillas. Core members of Guerilla Girls Broadband themselves take on the identities of female artists who have not gained the deserved appreciation in the male dominated art business. A "cartography of choice" maps abortion clinics and emails can be sent to "bad bosses" anonymously to address sexual harassment, unequal pay or other work-related grievances (Stein 2011).

Digital identity play has also become an important part of the annual 16 Days of Activism Against Gender-Based Violence. Established in 1991, this campaign has recently spread to Second Life, a virtual online environment for social roleplaying. Here feminist activists set up virtual discussion events, meetings, and exhibitions around the topic of gendered violence. Participants design female avatars with black eyes, bruises, and bleeding wounds to create awareness (Motter 2011). Protest avatars were also used in the Euro Mayday Netparades in 2004 and 2005. The annual Euro Mayday Parade draws attention to current precariousness of work, which especially affect women. On the website of the Mayday Netparade users could create their individual protest avatars as part of a diverse collective. According to a study by Mattoni and Doerr (2007), women, who are often underrepresented in the imagery of traditional Labor Day parades, took center stage online as "the parade's visual icons of protests positively underlined diversity and differences as an asset of the collective struggle" (132).

Other examples illustrate the relevance of racial and queer identity performances in claimed spaces on the internet. In 2004, a queer community established itself in the virtual roleplay fantasy game World of Warcraft. The fact that the 5,000 users of the community created 15,000 characters, including the practice of gender swapping, indicates playful identity exploration. Due to its global scope, this community also included participants from countries where homosexual practices are banned. Apart from political discussions on LGBTIQ issues, the community organized virtual Pride parades. Unlike the above examples were analog political protest was taken online, members of the LGBTIQ movement on World of Warcraft organized offline meetings after their online encounter (McKenna, Gardner, and Myers 2011). The digital enactment of difference is also evident in what became to be known as Habbo raids. In 2006 users of the imageboard 4chan charged moderators of Habbo Hotel - an online roleplay platform mostly used by white, US American teenagers - with discriminating against black avatars. 4chan users created a coordinated online swarm of black, male avatars in black suits with black sunglasses and big afros, which blocked entrances to facilities in the virtual hotel setting. When other users attempted to enter the virtual pool, the raiders exclaimed: "Pool's closed due to AIDS!" mocking racial prejudice (Author 2017). 
Identity exploration in claimed spaces on the internet does not require an entire virtual world with fully animated avatars like in the cases cited so far. Rather, social media provide tools for the everyday practice of identity play as part of political engagement. Gerbaudo (2015) demonstrates how users change their social media profile pictures for flags, logos or portraits of others or they decorate their own pictures with ribbons or color filters. In the so called "Arab Spring," for example, thousands of social media users changed their profile picture for the image of Khaled Said, a 28-year-old blogger killed by police in Alexandria. The strategy of difference enabled by online identity exploration thus also entails aspects of performing solidarity. At the same time, however, the carnivalesque construction of digital identities is also employed for discrimination and hate speech. In the so called "Gamer gate affair" twitter trolls using images of anime girls as profile pictures attacked feminists criticizing misogynist depiction of women in computer games, including death and rape threats (Author 2017). Another example is the online presence of the Ku Klux Klan who uses their website to visually construct a masculinist, heteronormative, and racially "pure" self-image (Schmitz 2016).

\section{Conclusion}

This essay set out to find new ways of furthering inclusion in democratic societies marked by identity related power asymmetries. It aims at contributing to the ideal of inclusion promoted by difference democrats while counteracting the essentializing tendencies inherent in their politics of presence. While the essentializing effects of the politics of presence themselves cannot be eliminated, they can be alleviated by a pluralization of alternative modes of identity performances. The multiplicity of identities which contribute to diversity as core value of democracy calls for the pluralization of institutional arrangements, which facilitate such diverse identity expression.

The typology presented here to account for such plural identity performances might appear as rigid. While the link between identity performances and their respective democratic function indeed proofs strong, the link with the respective space appears weaker. Examples illustrate that these identity performances with their respective function can work in other types of spaces as well. Koop and Marland (2012), for example, find that at least to a certain extent identity exploration is possible for representatives as they emphasize different aspects of themselves in different media. And some of my own work explores modes of identity negation in claimed spaces created by the hacktivist collective Anonymous (Author 2017).

The purpose of this paper is not to regulate identity performances and confine them to particular spaces. Rather than closing doors, I aim to open them and allow for new thinking. The goal is to draw attention to the diversity of modes of identity performances that are not mutually exclusive but can and must function alongside each other to fulfil a variety of democratic functions. This 
essay is a call for diversifying the types of participatory spaces and modes of identity performances as part of a pluralist democratic society. It is thus diversity - the core value of difference democracy - that leads the way out of the dilemma of difference. The essentializing tendencies of difference democracy are best countered by pluralizing participatory spaces and the variety of identity performances within them.

This argument needs, however, to be evaluated against the background of the perils of online communication such as group polarization, discrimination, and digital inequalities. Exclusion from online participation along gender, race, class, age, and geographic divides leaves these new possibilities of engagement out of reach for many. The factual increase in participatory possibilities, thus also widens gaps in political engagement. It is, however, important to note that these gaps are narrowing and are even overcome in the case of gender in the US, (Campos-Castillo 2015). As for all of these challenges, they often pose new threats to democracy. The wide spread of online communication is, however, a new emerging reality that needs to be faced. This reality brings both opportunities, which are the subject of this article, and challenges. Both are unavoidable and need to be dealt with with the greatest possible awareness, to which this article is a contribution.

The important question at this point is whether and to which extent participatory spaces on the internet exhibit negative effects observed in everyday communication. Group polarization described by Sunstein (2017) as a process in which communication among like-minded participants leads to more extreme positions has not been reported in any of the cases discussed above. The same applies for lying and fraud. It appears that design features of participatory spaces such as moderation and the awareness of their participants mitigates negative behavior exhibited elsewhere. This observation, however, does not apply for discrimination. As the examples of the Gamergate and the KKK online illustrate, some claimed spaces are created to pursue exclusionary purposes. This appears as trade-off coming along with freedom of expression. In short, anti-democratic tendencies exhibited in online communication are rather less pronounces in participatory spaces, who through their design and participants' awareness appear to discourage such behavior.

Discussions of difference democracy have long quietened down. But marginalized identities still account for modes of exclusion as recent studies show (Beauvais 2017; Karpowitz and Mendelberg 2014). This becomes even more evident in the face of new media's challenges such as cyberbullying and opportunities such as \#MeToo. Let Carole Pateman's words be an inspiration: "The lesson to be learned from the past is that a 'democratic' theory and practice that is not at the same time feminist merely serves to maintain a fundamental form of domination and so makes a mockery of the ideals and values that democracy is held to embody" (Pateman 1989, 223). 


\section{References}

Bächtiger, André, Markus Sörndli, Marco Steenbergen, and Jürgen Steiner. 2005. "The Deliberative Dimensions of Legislatures.” Acta Politica 40 (2): 225-38.

Bakhtin, Mikhail. 1968. Rabelais and His World. 1st ed. Cambridge, MA: MIT Press.

Beauvais, Edana. 2017. “Discursive Equality.” University of British Columbia.

Berg, Janne. 2017. "The Dark Side of E-Petitions? Exploring Anonymous Signatures." First Monday 22 (2): 1-11. doi:10.5210/fm.v22i2.6001.

Brock, Karen, Andrea Cornwall, and John Gaventa. 2001. "Power, Knowledge and Political Spaces in the Framing of Powerty Policy." 143. Working Papers of the Institute of Development Studies. Brighton.

Brophy, Jessica. 2010. "Developing a Corporeal Cyberfeminism: Beyond Cyberutopia.” New Media \& Society 12 (6): 929-45. doi:10.1177/1461444809350901.

Campos-Castillo, Celeste. 2015. "Revisiting the First-Level Digital Divide in the United States: Gender and Race/Ethnicity Patterns.” Social Science Computer Review 33 (4): 423-39.

Castells, Manuel. 2012. Networks of Outrage and Hope: Social Movements in the Internet Age. Cambridge: Politiy Press.

Coffé, Hilde, and Catherine Bolzendahl. 2010. "Same Game, Different Rules? Gender Differences in Political Participation." Sex Roles 62 (5-6): 318-33.

Cohen, Julie. 2012. Configuring the Networked Self: Law, Code, and the Play of Everyday Practice. New Haven/London: Yale University Press.

Coleman, Stephen. 2004. "Connecting Parliament to the Public via the Internet: Two Case Studies of Online Consultations.” Information, Communication \& Society 7 (1): 1-22.

Cornwall, Andrea. 2002. "Making Spaces, Changing Places: Situating Participation in Development.” 170. IDS Working Papers. Brighton.

—. 2004. "New Democratic Spaces? The Politics and Dynamics of Institutionalised Participation." IDS Bulletin 35 (2): 1-10.

Cornwall, Andrea, and Vera Schattan Coelho, eds. 2007. Spaces for Change? The Politics of Citzen Participation in New Democratic Arenas. 1st ed. London \& New York: Zed Books.

Danet, Brenda. 1998. "Text as Mask: Gender, Play, and Performance on the Internet." In Cybersociety 2.0: Revisiting Computer-Mediated Communication and Community, edited by Steven Jones, 129-58. Thousand Oaks: Sage. 
Daniels, Jessie. 2009. “Rethinking Cyberfeminism(s): Race, Gender, and Embodiment.” Women's Studies Quarterly 37 (1\&2): 101-24.

Davies, Todd, and Reid Chandler. 2012. "Online Deliberation: Choices, Criteria, and Evidence." In Online Democracy in Motion: Evaluating the Practice and Impact of Deliberative Civic Engagement, edited by Tina Nabatchi, John Gastil, Matt Leighninger, and G Michael Weiksner, 1-41. Oxford: Oxford University Press. doi:10.1093/acprof.

della Porta, Donatella, and Dieter Rucht. 2013. Meeting Democracy: Power and Deliberation in Global Justice Movements. Cambridge: Cambridge University Press.

Dryzek, John. 2000. Deliberative Democracy and Beyond: Liberals, Critics, Contestation. Oxford: Oxford University Press.

_. 2009. "Democtitization as Deliberative Capacity Building." Comparative Political Studies 42 (11): 1379-1402. doi:10.1177/0010414009332129.

Evans, Claire. 2018. Broad Band: The Untold Story of the Women Who Made the Internet. 1st ed. New York: Portfolio/Penguin.

Fernandez, Maria, and Faith Wilding. 2002. "Situating Cyberfeminism." In Domain Errors! Cyberfeminist Practices, edited by Maria Fernandez, Faith Wilding, and Michelle Wright, 1728. New York: Autonomedia and SubRosa.

Font, Joan, Graham Smith, Carol Galais, and P A U Alarcon. 2017. "Cherry-Picking Participation: Explaining the Fate of Proposals From Participatory Processes." European Journal of Political Research, 1-22. doi:10.1111/1475-6765.12248.

Fox, Richard, and Jennifer Lawless. 2014. "Uncovering the Origins of the Gender Gap in Political Ambition." American Political Science Review 108 (3): 499-519.

Fraser, Nancy. 1990. "Rethinking the Public Sphere: A Contribution to the Critique of Actually Existing Democracy." Social Text, no. 25/26: 56-80.

1996. "Equality, Difference, and Radical Democracy: The United States Feminist Debate Revisited.” In Radical Democracy: Identity, Citizenship, and the State, edited by David Trend, 197-208. New York: Routledge.

Fung, Archon, and Erik Olin Wright. 2001. "Deepening Democracy: Institutional Innovations in Empowered Participatory Governance." Politics \& Society 29 (1): 5-41.

Gajjala, Radhika, and Yeon Ju Oh, eds. 2012. Cyberfeminism 2.0. New York: Peter Lang Publishing.

Gaventa, John. 2006. "Finding the Spaces for Change: A Power Analysis." IDS Bulletin 37 (6): 
$23-33$.

Gerbaudo, Paolo. 2015. "Protest Avatars as Memetic Signifiers: Political Profile Pictures and the Construction of Collective Identity on Social Media in the 2011 Protest Wave." Information, Communication \& Society 18 (8): 916-29. doi:10.1080/1369118X.2015.1043316.

Gould, Carol. 1993. "Feminism and Democratic Community Revisited." In Democratic Community: NOMOS XXXV, edited by John Chapman and Ian Shapiro, 396-413. New York: New York University Press.

. 1996. "Diversity and Democracy: Representing Difference." In Democracy and Difference: Contesting the Boundaries of the Political, edited by Seyla Benhabib, 171-86. Princeton: Princeton University Press.

Grosz, Elizabeth. 2001. Architecture from the Outside: Essays on Virtual and Reals Space. Cambridge, MA: MIT Press.

Gulati, Girish. 2004. "Members of Congress and Presentation of Self on the World Wide Web." The International Journal of Press/Politics 9 (1): 22-40. doi:10.1177/1081180X03259758.

Haraway, Donna. 1991. "A Cyborg Manifesto: Science, Technology, and Socialist-Feminism in the Late Twentieth Century." In Simians, Cyborgs and Women: The Reinvention of Nature, 149-81. London: Free Association Books.

Jackson, Nigel, and Darren Lilleker. 2009. "MPs and E-Representation: Me, MySpace and I." British Politics 4 (2): 236-64. doi:10.1057/bp.2009.2.

—. 2011. "Microblogging, Constituency Service and Impression Management: UK MPs and the Use of Twitter." The Journal of Legislative Studies 17 (1): 86-105.

Joshi, Devin, and Erica Rosenfield. 2013. "MP Transparency, Communication Links and Social Media: A Comparative Assessment of 184 Parliamentary Websites." The Journal of Legislative Studies 19 (4): 526-45. doi:10.1080/13572334.2013.811940.

Karpowitz, Christopher, and Tali Mendelberg. 2014. The Silent Sex: Gender, Deliberation, and Institutions. Princeton: Princeton University Press.

Kolko, Beth. 2000. “Erase @race: Going White in the (Inter)Face.” In Race in Cyberspace, edited by Beth Kolko, Lisa Nakamura, and Gilbert Rodman, 213-32. New York/London: Routledge.

Koop, Royce, and Alex Marland. 2012. "Insiders and Outsiders: Presentation of Self on Canadian Parliamentary Websites and Newsletters" 4 (3): 112-35.

La Raja, Raymond. 2011. "Does Transparency of Political Activity Have a Chilling Effect on Participation?" In Meetings of the Midwest Political Science Association. Chicago. 
Mansbridge, Jane. 1983. Beyond Adversary Democracy. Chicago: University of Chicago Press. 1991. "Democracy, Deliberation and the Experience of Women." In Higher Education and the Practice of Democratic Politics: A Political Education Reader, edited by Bernard Murchland, 122-35. Dayton: Kettering Foundation.

1993. "Feminism and Democratic Community." In Democratic Community: NOMOS $X X X V$, edited by John Chapman and Ian Shapiro, 339-95. New York: New York University Press.

1998. "Feminism and Democracy." In Feminism and Politics, edited by Anne Phillips, 141-60. Oxford: Oxford University Press.

. 1999. "Should Blacks Represent Blacks and Women Represent Women? A Contingent 'Yes."' The Journal of Politics 61 (3): 628-57.

—. 2005. "Quota Problems: Combating the Dangers of Essentialism." Politics \& Gender 1 (4): 621-53. doi:10.1017/S1743923X05050191.

Mattoni, Alice, and Nicole Doerr. 2007. "Images Within the Precarity Movement in Italy." Feminist Review 87 (1): 130-35.

McKenna, Brad, Lesley Gardner, and Michael Myers. 2011. "Social Movements in World of Warcraft." In Proceedings of the Seventeenth Americas Conference on Information Systems, 1-8. Detroit.

Motter, Jennifer. 2011. "Feminist Virtual World Activism: 16 Days of Activism Against Gender Violence Campaign, Guerilla Girls BroadBand, and SubRosa." Visual Culture \& Gender 6: $108-18$.

Nakamura, Lisa. 2002. Cybertypes: Race, Ethnicity, and Identity on the Internet. New York/London: Routledge.

Nancy Burns, Kay Schlozman, Ashley Jardina, Shauna Shames, and Sidney Verba. 2018. "What Happened to the Gender Gap in Political Participaton? How Might We Explain It?" In 100 Years of the Nineteenth Amendment: An Appraisal of Women's Political Activism, edited by Holly McCammon and Lee Ann Banaszak, 69-104. Oxford: Oxford University Press.

Papacharissi, Zizi. 2011. A Networked Self: Identity, Community, and the Culture on Social Network Sites. New York: Routledge.

Pateman, Carole. 1989. The Disorder of Women: Democracy, Feminism, and Political Theory. Stanford: Stanford University Press.

Peixoto, Tiago, and Jonathan Fox. 2016. "Digital Dividends: When Does ICT-Enabled Citizen 
Voice Lead to Government Responsiveness?"

Phillips, Anne. 1991. Engendering Democracy. 1st ed. Cambridge: Polity Press.

1993. Democracy and Difference. Cambridge: Polity Press.

1995. The Politics of Presence. Oxford: Oxford University Press.

. 1996. "Dealing with Difference: A Politics of Ideas, or a Politics of Presence." In

Democracy and Difference: Contesting the Boundaries of the Political, edited by Seyla Benhabib, 139-52. Princeton: Princeton University Press.

- 1998. "Democracy and Representation: Or, Why Should It Matter Who Our Representatives Are?” In Feminism and Politics, edited by Anne Phillips, 224-40. Oxford: Oxford University Press.

Plant, Sadie. 1997. Zeros + Ones. London: 4th Estate Limited.

Polletta, Francesca. 2002. Freedom Is an Endless Meeting: Democracy in American Social Movements. Chicago: University of Chicago Press.

Rhee, June Wong, and Eun-mee Kim. 2009. "Deliberation on the Net: Lessons from a Field Experiment." In Online Deliberation: Design, Research, and Practice, edited by Todd Davies and Seeta Peña Gangadharan, 223-32. Chicago: University of Chicago Press.

Ruesch, Michelle Anna, and Oliver Märker. 2012. "Real Name Policy in E-Participation: The Case of Gütersloh's Second Participatory Budget.” In CeDEM12: Conference for E-Democracy and Open Government, edited by Peter Parycek and Noella Edelmann, 109-124. Krems: Edition Donau-Universität Krems.

Sanders, Lynn. 1997. “Against Deliberation.” Political Theory 25 (3): 347-76.

Schmidt, Jan-Hinrik, and Katharina Johnsen. 2014. "On the Use of the E-Petition Platform of the German Bundestag.” 3. HIIG Discussion Paper Series.

Schmitz, Rachel. 2016. "Intersections of Hate: Exploring the Transecting Dimensions of Race, Religion, Gender, and Family in Ku Klux Klan Web Sites.” Sociological Focus 49 (3). Routledge: 200-214. doi:10.1080/00380237.2016.1135029.

Setälä, Maija, and Kimmo Grönlund. 2006. "Parliamentary Websites: Theoretical and Comparative Perspectives." Information Polity 11 (2): 149-62.

Sick, Andrea. 2004. “Dream-Machine: Cyberfeminism.” In Cyberfeminism: Next Protocols, edited by Claudia Reiche and Verena Kuni, 49-64. New York: Autonomedia.

Smith, Graham. 2009. Democratic Innovations: Designing Institutions for Citizen Participation. 
Cambridge: Cambridge University Press.

Stanyer, James. 2008. "Elected Representatives, Online Self-Presentation and the Personal Vote: Party, Personality and Webstyles in the United States and United Kingdom." Information Systems Frontiers, Loughborough University’s Institutional Repository, 11 (3): 113-31.

Stein, Gertrude. 2011. "Guerrilla Girls and Guerrilla Girls BroadBand: Inside Story.” Art Journal 70 (2): 88-101. doi:10.1080/00043249.2011.10791003.

Stoycheff, Elizabeth. 2016. "Under Surveillance: Examining Facebook's Spiral of Silence Effects in the Wake of NSA Internet Monitoring." Journalism \& Mass Communication Quarterly 93 (2): 1-16. doi:10.1177/1077699016630255.

Sunstein, Cass. 2017. \#Republic: Divided Democracy in the Age of Social Media. Princeton: Princeton University Press.

Turkle, Sherry. 1984. The Second Self: Computers and the Human Spirit. London: Granada.

Volkart, Yvonne. 2004. "The Cyberfeminist Fantasy of the Pleasure of the Cyborg." In Cyberfeminism: Next Protocols, edited by Claudia Reiche and Verena Kuni, 97-117. New York: Autonomedia.

Wajcman, Judy. 2004. TechnoFeminism. Cambridge: Polity Press.

Wright, Scott. 2012. "The Participatory Journey in Online Consultations." In Connecting Democracy: Online Consultation and the Flow of Political Communication, edited by Stephen Coleman and Peter Shane, 149-72. Cambridge, MA: MIT Press.

Young, Iris Marion. 1990. Justice and the Politics of Difference. Princeton: Princeton University Press.

1994. “Gender as Seriality: Thinking about Women as a Social Collective.” Signs 19 (3): $713-38$.

. 1997a. "Deferring Group Representation." In Ethnicity and Group Rights, edited by Ian Shapiro and Will Kymlicka, 349-76. New York: New York University Press.

. 1997b. "Difference as a Resource for Democratic Communication." In Deliberative Democracy: Essays on Reason and Politics, edited by James Bohman and William Rehg, 383-406. Cambridge: MIT Press.

2000. Inclusion and Democracy. Oxford: Oxford University Press. 
${ }^{1}$ This criticism has been responded to in various accounts of deliberative democracy with relaxations of consensus requirements and explanations of rationality as intersubjective for example by Dryzek (2000). Here this criticism merely functions to explain the starting point of debates around difference democracy.

${ }^{2}$ While the literature in development studies speaks of closed, invited and claimed spaces, Dryzek speaks of empowered and public spaces. Closed and empowered spaces refer to state institutions. Public spaces encompass both claimed and invited spaces. I bring these two terminologies together, because they supplement each other. On the one hand, Dryzek's terminology lacks a differentiation between invited and claimed spaces and collapses them into public spaces. On the other, the terminology of development studies is not consistent. The attributes "claimed" and "invited" describe how participants get access to the respective participatory space. The term "closed" does not describe modes of access but appears to deny access altogether." The term empowered," however, explains that participant in state institutions get access via modes of empowerment, either through elections or appointment. While these processes are highly exclusive, they are not entirely closed. 